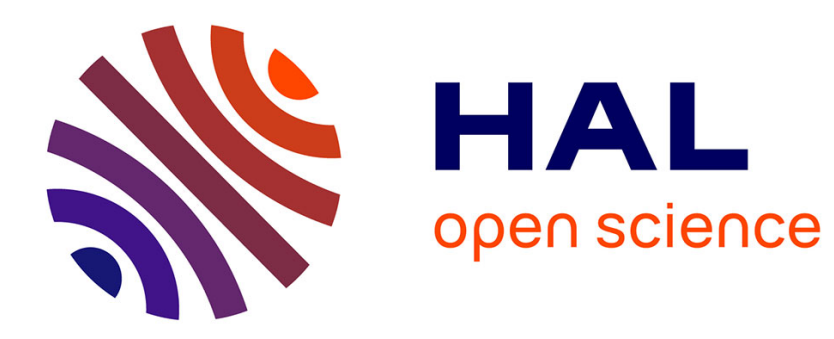

\title{
Effect of tomato deleafing on mirids, the natural predators of whiteflies
}

Olivier Bonato, Gilles Ridray

\section{To cite this version:}

Olivier Bonato, Gilles Ridray. Effect of tomato deleafing on mirids, the natural predators of whiteflies. Agronomy for Sustainable Development, 2007, 27 (3), pp.167-170. 10.1051/agro:2007011. hal02668677

\section{HAL Id: hal-02668677 https: / hal.inrae.fr/hal-02668677}

Submitted on 31 May 2020

HAL is a multi-disciplinary open access archive for the deposit and dissemination of scientific research documents, whether they are published or not. The documents may come from teaching and research institutions in France or abroad, or from public or private research centers.

$$
\text { Copyright }
$$

L'archive ouverte pluridisciplinaire HAL, est destinée au dépôt et à la diffusion de documents scientifiques de niveau recherche, publiés ou non, émanant des établissements d'enseignement et de recherche français ou étrangers, des laboratoires publics ou privés. 


\title{
Effect of tomato deleafing on mirids, the natural predators of whiteflies
}

\author{
O. BONATO ${ }^{a}$, G. RIDRAY ${ }^{\mathrm{b}}$ \\ ${ }^{a}$ IRD-Center for Biology and Management of Populations (CBGP), CS 30 016, 34988 Montferrier-sur-Lez Cedex, France \\ ${ }^{\mathrm{b}}$ INRA Domaine expérimental du Mas blanc, 66200 Alenya, France
}

(Accepted 11 January 2007)

\begin{abstract}
Sustainability in Mediterranean greenhouse agrosystems involves environmentally-friendly techniques based on biological and non-chemical methods. Deleafing is a common agricultural practice used to accelerate fruit ripening and facilitate farming methods. However, deleafing may have an impact on mirids, a natural predator used to control whiteflies, which are considered among the most noxious insect pests of field and greenhouse crops worldwide. Here we studied the impact of leaf removal on populations of mirids. Two deleafing practices were tested: (a) regular deleafing, with the first removal of 2 leaves per plant 10 weeks after sowing; and (b) delayed deleafing, in which the first removal was delayed by 14 days. Our results show that regular deleafing had a strong negative impact on mirid populations. Indeed, the first deleafing of the regular method eliminated $74 \%$ of young nymphs. Such a loss was not observed with the delayed method because nymphs were older and already distributed on leaves which were never thinned. As a consequence of this initial difference, mirid populations were $60 \%$ higher in the delayed than in the regular deleafing treatments at the end of the crop. The biological control of whiteflies was less efficient in the regular deleafing crop for which densities were, on average, $30 \%$ higher than in the delayed deleafing crop. Such inefficiency could call into question the sustainability in protected tomato crops of environmentally-friendly techniques focused on reducing the pesticides used.
\end{abstract}

deleafing / impact / Macrolophus caliginosus / Bemisia tabaci / Trialeurodes vaporariorum / tomato

\section{INTRODUCTION}

The seriousness of the economic impact of whitefly and whitefly-transmitted virus complexes worldwide, up to $85 \%$ of crop yield losses, has resulted in accelerated research to provide acceptable management methods in crop protection (Oliveira et al., 2001). Integrated pest management (IPM), based on the integration of cultural, biological and nonchemical methods, is a goal for sustainable greenhouse crops (Ferron and Deguine, 2005), particularly vegetables and ornamentals (Van Lenteren, 2000). Sustainability in Mediterranean greenhouse agrosystems is mainly characterised by environmentally-friendly techniques focused on the high quality of the products such as high percentage of dry matter, low pesticide residues and low nitrate content (De Pascale and Maggio, 2005). Although biological control agents, such as predators and parasites, are the cornerstone of the success of IPM (Van Lenteren and Van Woets, 1988), little attention has been paid to quantifying the indirect impacts of crop practices on natural enemy action. In the Mediterranean region, the mirid Macrolophus caliginosus (Wagner) is an efficient predator commonly used to control the whiteflies Trialeurodes vaporariorum (Westwood) and Bemisia tabaci (Gennadius) in greenhouse crops of tomatoes (Malausa and Trottin-Caudal, 1996; Sampson and King, 1996; Schelt et al., 1996). However, difficulties are regularly encountered to establish the predator (Ridray and Trottin-Caudal, 2001).

It has been hypothesised that crop practices such as deleafing could have an impact on Macrolophus populations. De-

*Corresponding author: bonato@mpl.ird.fr leafing is a common agricultural practice in tomato crops and essentially responds to specific criteria, i.e., production and yield quality (Slack, 1981, 1986). It consists of progressively removing old leaves with poor photosynthetic activity from the lower strata. Leaf removal accelerates fruit coloration and maturation by improving light conditions. In addition, it facilitates fruit harvest and, by increasing air circulation between plants, reduces the development of fungal diseases. However, the effect of deleafing on mirid populations, which protect tomato plants by preying upon whiteflies, is not known. Here we investigated whether deleafing could eliminate eggs of mirids, which are inserted into the leaf tissues, and whether it could increase the mortality of young nymphs, which may be unable to move to tomato plants from the leaves left on the ground.

\section{MATERIALS AND METHODS}

The experiments were conducted between October 2002 and June 2003 at the INRA centre in Alenya (southern France) in a greenhouse which was split into 4 identical compartments of $150 \mathrm{~m}^{2}$ each using whitefly-proof screen. The tomato variety "Clotilde" ("cluster type") was sown during the last week of October 2002, and grown in a nursery for one month under a whitefly-proof screen. The predator M. caliginosus was introduced on plants once in the nursery 2 weeks after sowing, at a density of 1.75 adults per plant. On the day of introduction, the bugs were fed with eggs of Ephestia kuehniella (0.03 g/plant) as recommended by Ridray et al. (1998). Thereafter, the crop was grown in the greenhouse. The plants were naturally infested by $T$. vaporariorum and B. tabaci. Emergence of 1 st 


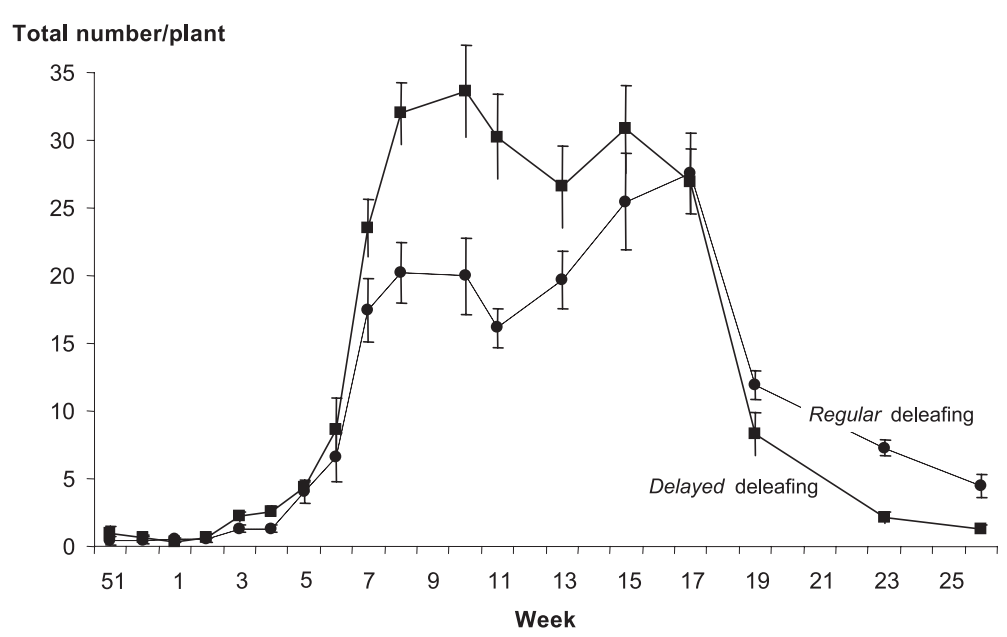

Figure 1. Number of whiteflies (adults and old nymphs) on tomato plants for the two deleafing practices (delayed and regular) tested. The biological control of whiteflies by the predatory bug (mirid) was less efficient in the regular deleafing crop for which densities were, on average, $30 \%$ higher than in the delayed deleafing crop.

generation Macrolophus nymphs began one month after the introduction of the adults. During the 3 weeks following nymph emergence, $0.02 \mathrm{~g}$ of eggs of E. kuehniella $/ \mathrm{m}^{2}$ were provided weekly to avoid food limitation and thus facilitate predator development.

Whiteflies and $M$. caliginosus populations were monitored in each of the four compartments throughout the experiment. The sampling unit was an entire plant. All plants belonging to a compartment were numbered and 12 plants per compartment were chosen by drawing lots. Each plant (sample) was stratified into levels, each level corresponding to the leaves (usually 3) present between two bunches. The lowest and oldest leaves situated under the first bunch were called level 0 . At each sampling, the young and old nymphs and adults of Macrolophus and old nymphs and adults of whiteflies found at each level were counted separately. Macrolophus nymphs present on the leaves that were removed were also counted. Sampling was done weekly from week 8 after sowing to week 17 after sowing. From week 18 to the last harvest, at week 35, eight further samplings were carried out.

Two deleafing methods were tested, the regular procedure in two compartments $\left(R_{1}, R_{2}\right)$ and the delayed procedure in the two others $\left(D_{1}, D_{2}\right)$ :

The regular procedure is commonly used by producers. In our study the first removal of 2 leaves per plant took place 10 weeks after sowing, followed one week later by the removal of 5 more leaves per plant; then from week 15 until week 19, three more deleafings of 3 leaves per plant were carried out to obtain plants with only 16 leaves one week before the first harvest. Sixteen leaves per plant were maintained from week 19 until the end of the crop by removing the necessary number of leaves at two-weekly or monthly intervals.

In the delayed procedure, the first removal $(2+$ 5 leaves/plant) was delayed by 14 days until weeks 12 and 13 after sowing. In addition, to facilitate optimal migration of Macrolophus nymphs within the tomato plants, 20 leaves were left on each plant one week before the first harvest in week 19 and subsequently the plants were maintained with 22 leaves.

Statistical analyses. Before pooling replicates to obtain one set of data per treatment (regular or delayed) and per population (whiteflies or predators), a Mann-Whitney test was performed between replicates, i.e. $R_{1}$ compared with $R_{2}$, and $D_{1}$ with $D_{2}$. Data for weeks $10,12,16,19$ and 25 after sowing and for week 34 (the end of the experiment) were analysed. The number of $M$. caliginosus present before and after leaf removal in each treatment was compared with a Mann-Whitney test $(\alpha=0.05)$. The proportion of young and old nymphs observed before deleafing (regular or delayed) was compared using a $\chi^{2}$ test $(\alpha=0.05)$.

\section{RESULTS AND DISCUSSION}

\subsection{Phenology of whiteflies and $M$. caliginosus populations}

Whiteflies and mirid populations were monitored on plants in each of the four compartments. Compartments $R_{1}$ and $R_{2}$ correspond to the Regular deleafing method tested, and $D_{1}$ and $D_{2}$ to the Delayed one. Because no significant difference was found between $R_{1}$ and $R_{2}$ or between $D_{1}$ and $D_{2}(P<0.05$, $v=22$ ), data were pooled for each treatment (regular or delayed). Whitefly populations consisting mostly of Trialeurodes vaporariorum (85\%) were observed 3 weeks after transferral of plants from the nursery to the greenhouse (Fig. 1).

From week 11 to week 18, whiteflies increased rapidly at a similar rate in both procedures to reach a maximum of 33 and 17 individuals per plant with the delayed and regular procedure, respectively. From week 25 on, a constant decrease was observed until the end of the cropping cycle. For M. caliginosus (Fig. 2), a very homogeneous cohort of young 1st generation nymphs was observed from week 7 onwards, with similar densities in both treatments. In week 11, a drastic decrease associated with the first deleafing was observed with 
Total number/plant

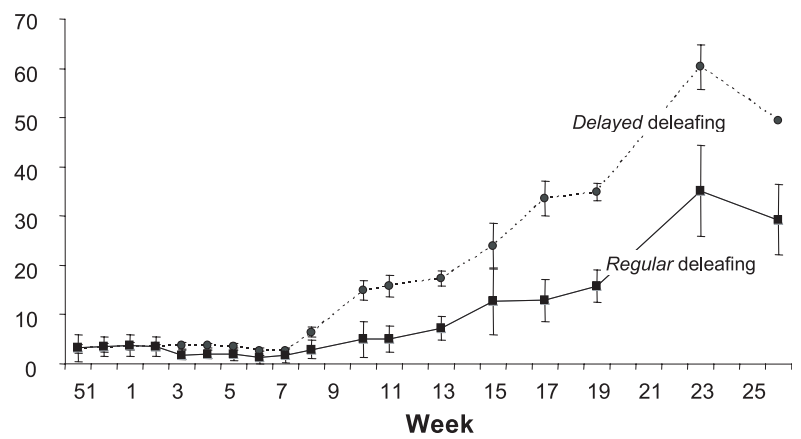

Figure 2. Number of Macrolophus caliginosus (adults and old nymphs) on tomato plants for the two deleafing practices (delayed and regular) tested. The gap created by the first leaf removal increased and led to significant differences between mirid populations which were, at the end of the crop, $60 \%$ higher in delayed than in regular deleafing.

the regular treatment. The difference between the two treatments remained stable until week 15 after sowing. Thereafter, corresponding to the emergence of 2 nd generation nymphs, the difference between the two treatments increased, with the lowest densities of $M$. caliginosus observed with the delayed treatment. Statistical analyses performed in weeks 10, 12, 16, 19, 25 and 34 (after sowing) showed that except for week 10 where $P>0.05$, there was always a significant difference in $M$. caliginosus populations between the delayed and regular treatment $(P<0.001)$.

\subsection{Impact of the first deleafing on $M$. caliginosus dynamics}

Special attention was paid to the age-structure relationship of the population in the period encompassing first leaf removal for both practices. With the regular treatment, a drastic decrease in young nymphs was observed just after the first deleafing (Fig. 3), which was not offset by an equivalent increase in the number of older nymphs. Thus, one week after deleafing, the total number of $M$. caliginosus (nymphs and adults) decreased significantly by almost $50 \%(P<0.001 ; \mathrm{Z}=1.96$; $\left.\mathrm{Z}_{\text {calculated }}=7.85\right)$. In the delayed treatment (Fig. 4), leaf removal had no effect on young nymphs because they had already passed to an older stage by the time deleafing took place, and there was thus no significant loss of predators $(P>0.05$; $\left.Z=1.96 ; Z_{\text {calculated }}=1.65\right)$.

Intra-plant distribution of Macrolophus nymphs was also studied. For both practices, until week 2, $80 \%$ of the first generation of young nymphs was recovered at level 0 , which is the oldest level (Tab. I). Subsequently, the nymphs were distributed among higher levels that were never thinned. When the first regular thinning took place, $80 \%$ of the nymph population was located under the first bunch and comprised $80 \%$ of young individuals with poor moving ability. Two weeks later, in the delayed procedure, the nymphs were older, mobile and already present at all plant levels. Only $20 \%$ of the

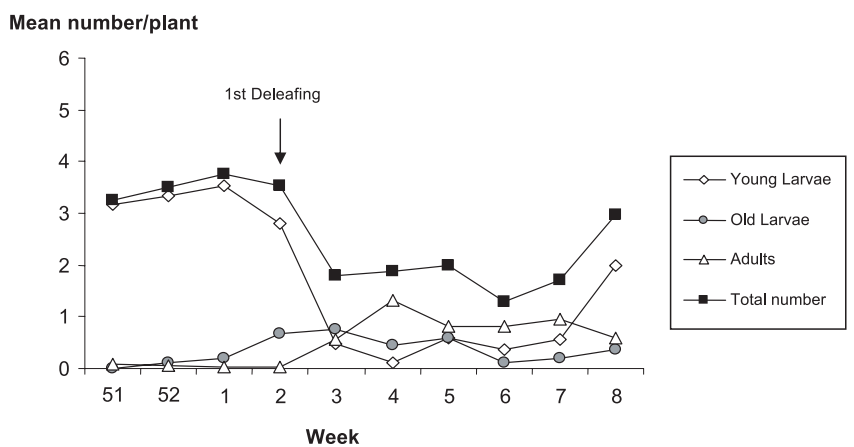

Figure 3. Population structure of Macrolophus caliginosus, a biological agent used to control whiteflies on tomato, for the regular deleafing practice. The drastic decrease in young nymphs observed just after the first deleafing was not offset by an equivalent increase in the number of older nymphs and there was thus a significant loss of predators.

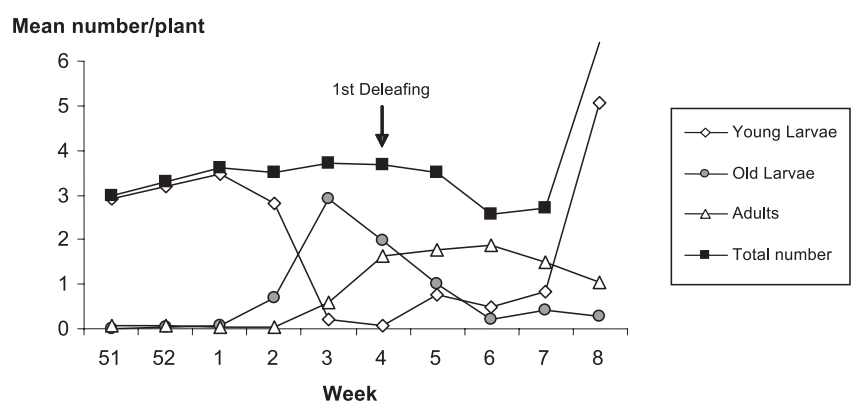

Figure 4. Population structure of Macrolophus caliginosus, a biological agent used to control whiteflies on tomato, for the delayed deleafing practice. The first deleafing had no effect on young nymphs because they had already passed to an older stage and there was thus no significant loss of predators.

nymphs were recovered at level 0 . To support the hypothesis that exportation of nymphs at first deleafing was responsible for the difference in population densities between the two practices, at each leaf-removal operation (except the last one) we also counted the number of nymphs present both on the plant before deleafing and on the leaves that were removed (Tab. I). Our results showed that at the first deleafing in the regular treatment only, a significant number of nymphs was eliminated (74\%).

\section{CONCLUSION}

We showed that the common practice of regular deleafing has a strong negative influence on the development of M. caliginosus mirid populations. The first deleafing is highly effective as it eliminates almost all the young nymphs (74\%) belonging to the first generation, thereby delaying the increase in the population. Because $M$. caliginosus mirids are used as a biological agent to control whiteflies, it is important that populations of this natural enemy of whiteflies reach high densities as fast as possible. Well-established populations of mirids are 
Table I. Percentage of young and old nymphs of Macrolophus caliginosus found on level 0 of tomato plants before the first deleafing of both the regular and delayed practices and percentage of nymphs (old and young) removed by deleafing.

\begin{tabular}{cll}
\hline & Regular & Delayed \\
\hline \% of individuals present & & \\
\hline Young nymphs & 80 & 10 \\
\hline Old nymphs & 20 & 90 \\
\hline$\%$ of nymphs removed & 74 & 0.1 \\
\hline
\end{tabular}

able to maintain whiteflies at low densities and therefore drastically reduce pesticide use. A two-week delay in deleafing, which corresponds to approximately 6 leaves, significantly reduced losses of the $M$. caliginosus mirids. The young nymphs had already developed to older stages, and were thus more mobile and better distributed throughout the plant. Therefore, only $0.1 \%$ were lost, compared with the $74 \%$ in the regular deleafing. Because deleafing essentially corresponds to production and yield quality criteria, the delayed practice we propose represents a good compromise between production requirements and the sustainability of non-chemical methods.

\section{REFERENCES}

De Pascale S., Maggio A. (2005) Sustainable protected cultivation at a Mediterranean climate. Perspective and challenges, Proc. International Conference on Sustainable Greenhouse Systems, Acta Hort. 691, 29-42. [Proc. IC on Greensys, ISHS 2005, Acta Hort. 691, 29-42.]

Ferron P., Deguine J.-P. (2005) Crop protection, biological control, habitat management and integrated farming. A review, Agron. Sustain. Dev. $25,17-24$.
Lenteren van J.C., Woets J. van (1988) Biological and integrated control in greenhouses, Ann. Rev. Entomol. 33, 239-269.

Lenteren van J.C. (2000) A greenhouse without pesticides: fact or fantasy? Crop Prot. 19, 375-384.

Malausa J.C., Trottin-Caudal Y. (1996) Advances in the strategy of use of the predaceous bug Macrolophus caliginosus in glasshouse crops, in: Alomar O., Weidenmann R.N. (Eds.), Zoophytophagous heteroptera: Implications for life history and Integrated Pest Management, Entomol. Soc. Am., Lanham, pp. 178-189.

Oliveira M.R.V., Henneberry T.J., Anderson P. (2001) History, current status, and collaborative research projects for Bemisia tabaci, Crop Prot. 20, 709-723.

Ridray G., Lenfant C., Sausseau E. (1998) Tomate en lutte intégrée : des lâchers en pépinière, Fruits et légumes 167, 64-67.

Ridray G., Trottin-Caudal Y. (2001) Introduction du prédateur Macrolophus caliginosus en pépinière de tomate, Bilan de trois années d'expérimentations, Rencontres Phytosanitaires Légumes CTIFL/SPV, 24-25 Jan. 2001, Caen, France, Ed. CTIFL/SPV, pp. $1-2$.

Sampson A.C., King V.J. (1996) Macrolophus caliginosus, field establishment and pest control effect in protected tomatoes, IOBC WPRS Bull. 19, 143-146.

Schelt J. van, Klapwijk J., Letard M., Aucouturier C. (1996) The use of Macrolophus caliginosus as a whitefly predator in protected tomatoes, in: Gerling D., Mayer R.T. (Eds.), Bemisia 1995, Taxonomy, Biology, Damage, Control and Management; Intercept Ltd, Andover, pp. 515-521.

Slack G. (1981) Glasshouse tomatoes. De-leafing to what effect, Grower $95,16-21$.

Slack G. (1986) The effects of leaf removal on the development and yield of glasshouse tomatoes, J. Hort. Sci. 61, 353-360. 